\title{
Clinical Characteristics And Outcomes of 16 Cases With COVID19 and Mucormycosis: Experience From A Tertiary Care Center In India and Review of Literature
}

\section{Saurav Sekhar Paul}

All India Institute of Medical Sciences

Rohit Kumar ( $\sim$ drrohitkgarg@gmail.com )

All India Institute of Medical Sciences https://orcid.org/0000-0001-8203-0323

\section{Ved Prakash Meena}

All India Institute of Medical Sciences

\section{Aishwarya Ramprasad}

All India Institute of Medical Sciences

\section{Prerna Garg}

All India Institute of Medical Sciences Vishakh C Keri

All India Institute of Medical Sciences Komal Singh

All India Institute of Medical Sciences Ankita Dhir

All India Institute of Medical Sciences Pirabu Sakhtivel

All India Institute of Medical Sciences Saurabh Vig

All India Institute of Medical Sciences

Anuja Pandit

All India Institute of Medical Sciences

Pavan Tiwari

All India Institute of Medical Sciences

Gagandeep Singh

All India Institute of Medical Sciences

Ekta Dhamija

All India Institute of Medical Sciences

Manish Soneja

All India Institute of Medical Sciences

Immaculata Xess

All India Institute of Medical Sciences

\section{Alok Thakar}

All India Institute of Medical Sciences

\section{Sushma Bhatnagar}

All India Institute of Medical Sciences

Anant Mohan

All India Institute of Medical Sciences

Naveet Wig

All India Institute of Medical Sciences

\section{Research Article}

Keywords: mucormycosis, infection, healthcare, diagnosis

Posted Date: May 20th, 2021

DOI: https://doi.org/10.21203/rs.3.rs-533347/v1

License: (c) (1) This work is licensed under a Creative Commons Attribution 4.0 International License. Read Full License 


\section{Abstract}

Background-The sharp uptick in the cases of mucormycosis in the background of the COVID19 pandemic is a cause of concern and the reasons and it's impact remains to be seen. We studied the clinical characteristics in patients with mucormycosis and COVID19 co-infection and performed a literature review.

Methods-This retrospective study was conducted at tertiary centre in India. All patients admitted with COVID19 and mucormycosis were included, clinical details were obtained from hospital records. We did review of literatures using the terms "SARS-CoV2" OR "COVID19" AND "Mucormycosis" AND "co-infection" on Pubmed published before February 20, 2021.

Results-Sixteen cases (M:F-13:3), mean age 46.5 years (24-75years), were included. Fourteen had known risk factors for mucormycosis, the most common being diabetes mellitus. Most patients $(n=14)$ were symptomatic with mucormycosis before diagnosis of COVID19. There was delay in surgery by 22.5 days (IQR->17.75-29.5), pending SARS-CoV-2 RT-PCR negativity. There were six deaths in this cohort, unrelated to the COVID19 severity. The literature review revealed eleven case reports on co-infection. Patients who had developed mucormycosis were found to have history of mechanical ventilation.

Conclusion-The apparent increase in the incidence of mucormycosis may be due to decompensation of underlying comorbidities (decreased access to healthcare), and increased use of immunosuppressants in COVID19. Patients with co-infection were noted to have poorer outcomes.

\section{Introduction}

Even after more than one year following the origin of the pandemic the pathogenesis of COVID19 remains partially understood and understanding of the same continues to evolve with time. As the highly infectious virus continues to give rise to new cases globally, one of the biggest concerns is co-existing infections. Co-infections or superinfections are deemed to occur as the pandemic tends to overlap with geographical realm and seasonality for few infections or due to the encounter with other community or nosocomial pathogens (during hospitalisation for COVID-19). However, information on co-infections in COVID19, especially with relation to invasive fungal infections, is lacking.

Multiple cases of invasive pulmonary aspergillosis (CAPA - COVID19 associated pulmonary aspergillosis) and invasive candidiasis (CAC - COVID19 associated candidiasis) have been reported in patients with severe COVID19 (1). This has been linked to the use of steroids, long-term antimicrobials, prolonged mechanical ventilation, and the extended duration of hospital stay in these patients. There is growing concern over the increase in cases of mucormycosis in COVID19 as well. Mucormycosis is an angio-invasive disease caused by opportunistic fungi of the order Mucorales in immunocompromised patients.(2) Untreated mucormycosis is almost always fatal. It remains to be seen if this increasing incidence of mucormycosis in COVID19 is related to the illness itself, the steroids and immunomodulators administered for treatment, or the worsening of underlying predisposing factors in the socio-economic upheaval caused by the pandemic. Further, it is unknown how the co-existence of COVID19 would affect the natural history and treatment of patients with mucormycosis.

To answer some of these questions, we performed a retrospective clinico-epidemiological study on patients with COVID19 and mucormycosis co-infection.

\section{Methods}

This was a retrospective, observational study, conducted at All India Institute of Medical Sciences, New Delhi, India. Patients admitted between March 20, 2020 and January 31, 2021 with current, recent, or remote history of COVID19 AND diagnosed mucormycosis were included in the study. The diagnosis of mucormycosis was based on either the histopathological demonstration of hyphae consistent with mucormycetes, i.e., hyaline, broad, aseptate, or pauciseptate, ribbon-like hyphae with right/obtuse-angled branching in the hematoxylin and eosin (H \& E)/ Periodic Acid Schiff's (PAS)/ Gomori's methenamine silver (GMS) staining or on culture isolation of the mucormycetes, in the tissue specimens obtained from suspected sites, as per the ECMM/MSG-ERC-2019 (European Confederation of Medical Mycology in cooperation with the Mycoses Study Group Education and Research Consortium) diagnostic criteria.

Patients without microbiological or histopathological evidence of mucormycosis were excluded from the study. Written informed consent was obtained in all cases. Hospital records were scanned, and missing details were filled in through telephonic or direct interviews with patients. Information on demography, clinical features, investigations, treatment, and outcomes was collected. Mucormycosis was classified based on the site of involvement into sino-nasal disease, rhino-orbital, rhino-orbito-cerebral, or pulmonary disease. Sino-nasal disease was defined as infection limited to sinus and nasal cavities only without orbital or intracranial extension. Rhino-orbital or rhino-orbital-cerebral disease included fungal invasion into orbit or intracranial cavity to involve orbital contents or intracranial structures, respectively. Orbital involvement was defined as vision diminution or ophthalmoplegia and definitive radiological evidence of the same. Brain parenchymal involvement was defined as focal neurological deficits or altered mentation with radiological evidence of intracranial extension. Pulmonary disease was defined as radiological, histopathological, or microbiological evidence of fungal infection in the lung parenchyma. The protocol for the study was approved by the Institutional Ethics Committee.

\section{Results}

Between March 20, 2020 and January 31, 2020, 6250 cases of COVID19 were admitted at our centre. Of these, sixteen patients were (M: F 13:3) with a mean age of 46.5 years (SD, 14.5) were diagnosed with mucormycosis and were included in our study (Table 1). Fifteen patients had one or more comorbidities (Table 3), most commonly uncontrolled diabetes mellitus $(n=12)$, chronic kidney disease $(n=2)$, solid-organ transplantation ( $n=1)$, hematological malignancy $(n=1)$, decompensated chronic liver disease $(n=1)$ and chronic granulomatous disease $(n=1)$. Three out of twelve diabetic patients had presented with diabetic ketoacidosis. 
Table 1

- Demography, clinical features, management, and outcom

\begin{tabular}{|c|c|c|c|c|c|c|c|c|}
\hline & Patient 1 & Patient2 & Patient 3 & Patient 4 & Patient 5 & patient 6 & patient 7 & Patic \\
\hline Age/Sex & $62 / \mathrm{M}$ & $70 / \mathrm{M}$ & $53 / \mathrm{M}$ & $47 / M$ & $38 / \mathrm{M}$ & $37 / M$ & $32 / \mathrm{M}$ & $48 / \mathrm{N}$ \\
\hline \multirow[t]{2}{*}{ Comorbidities } & \multirow[t]{2}{*}{ DM } & \multirow[t]{2}{*}{ DM } & $\mathrm{DM}$ & \multirow[t]{2}{*}{ DM } & \multirow{2}{*}{$\begin{array}{l}\text { Post renal } \\
\text { transplant on } \\
\text { immune- } \\
\text { suppression, DM }\end{array}$} & \multirow{2}{*}{$\begin{array}{l}\text { Decompensated } \\
\text { CLD (Child C), } \\
\text { DM }\end{array}$} & \multirow[t]{2}{*}{ CGD } & \multirow[t]{2}{*}{$\mathrm{DM}$} \\
\hline & & & CKD-3 & & & & & \\
\hline $\begin{array}{l}\text { COVID-19 } \\
\text { severity }\end{array}$ & Mild & asymptomatic & asymptomatic & Not known & severe & asymptomatic & Mild & Mild \\
\hline $\begin{array}{l}\text { RT-PCR } \\
\text { positivity } \\
\text { duration }\end{array}$ & 30 days & 10 days & 10 days & NA & 28 days & 24 days & 16 days & $18 \mathrm{~d}$ \\
\hline $\begin{array}{l}\text { Duration of } \\
\text { symptoms }\end{array}$ & 10 days & 12 days & 10 days & 15 days & 15 days & 6 days & 20 days & $40 \mathrm{~d}$ \\
\hline $\begin{array}{l}\text { Temporality of } \\
\text { diagnosis of } \\
\text { mucormycosis } \\
\text { to COVID-19 }\end{array}$ & Pre-COVID-19 & Pre-COVID-19 & Pre-COVID-19 & Pre-COVID-19 & Post COVID-19 & Pre-COVID-19 & Pre-COVID-19 & Pre-C \\
\hline $\begin{array}{l}\text { Clinical } \\
\text { features }\end{array}$ & $\begin{array}{l}\text { Right } \\
\text { periorbital } \\
\text { swelling with } \\
\text { oculopareis, } \\
\text { diminution of } \\
\text { vision, } \\
\text { multiple C.N } \\
\text { palsy, necrotic } \\
\text { palatal ulcer, } \\
\text { DKA }\end{array}$ & $\begin{array}{l}\text { Left facial } \\
\text { pain, } \\
\text { mucopurulent } \\
\text { nasal } \\
\text { discharge }\end{array}$ & $\begin{array}{l}\text { Left sided } \\
\text { periorbital and } \\
\text { malar swelling, } \\
\text { proptosis and } \\
\text { external } \\
\text { ophthalmoplegia, } \\
\text { diminution of } \\
\text { vision, necrotic } \\
\text { palatal ulcer, } \\
\text { Right } \\
\text { hemiparesis }\end{array}$ & $\begin{array}{l}\text { Right } \\
\text { periorbital } \\
\text { and malar } \\
\text { swelling, } \\
\text { proptosis, } \\
\text { ophthalmo- } \\
\text { plegia, } \\
\text { diminution of } \\
\text { vision, left } \\
\text { hemiplegia, } \\
\text { altered } \\
\text { sensorium; } \\
\text { DKA }\end{array}$ & $\begin{array}{l}\text { Left sided } \\
\text { periorbital } \\
\text { swelling, } \\
\text { proptosis, } \\
\text { diminution of } \\
\text { vision }\end{array}$ & $\begin{array}{l}\text { Altered } \\
\text { sensorium, } \\
\text { nasal discharge, } \\
\text { epistaxis }\end{array}$ & $\begin{array}{l}\text { Right eye } \\
\text { proptosis, } \\
\text { ophthalmo- } \\
\text { plegia, } \\
\text { diminution of } \\
\text { vision, } \\
\text { multiple C.N } \\
\text { palsy }\end{array}$ & $\begin{array}{l}\text { Right } \\
\text { perio } \\
\text { mala } \\
\text { swell } \\
\text { ophtl } \\
\text { plegi } \\
\text { dimir } \\
\text { visio } \\
\text { multi } \\
\text { palsy }\end{array}$ \\
\hline Site involved & $\begin{array}{l}\text { Rhino-orbital- } \\
\text { cerebral }\end{array}$ & Sino-nasal & $\begin{array}{l}\text { Rhino-orbito- } \\
\text { cerebral }\end{array}$ & $\begin{array}{l}\text { Rhino-orbito- } \\
\text { cerebral }\end{array}$ & Rhino-sino-orbital & Sino-nasal & $\begin{array}{l}\text { Rhino-orbito- } \\
\text { cerebral }\end{array}$ & $\begin{array}{l}\text { Rhinı } \\
\text { ceret }\end{array}$ \\
\hline Mycological & $\mathrm{KOH}+$ & $\mathrm{KOH}+$ & $\mathrm{KOH}+$ & $\begin{array}{l}\text { Rhizopus } \\
\text { arrhizus }\end{array}$ & $\mathrm{KOH}+$ & $\mathrm{KOH}+$ & $\mathrm{KOH}+$ & $\mathrm{KOH}$ \\
\hline Histopathology & $\begin{array}{l}\text { Angio- } \\
\text { invasion } \\
\text { present }\end{array}$ & $\begin{array}{l}\text { Angio- } \\
\text { invasion with } \\
\text { necrosis }\end{array}$ & $\begin{array}{l}\text { Angio-invasion } \\
\text { with perinural } \\
\text { invasion, } \\
\text { osteonecrosis }\end{array}$ & NA & $\begin{array}{l}\text { angioinvasion } \\
\text { with perineural } \\
\text { invasion, chronic } \\
\text { inflammation }\end{array}$ & NA & angioinvasion & $\begin{array}{l}\text { chror } \\
\text { inflar }\end{array}$ \\
\hline Radiology & $\begin{array}{l}\text { Pan-sinusitis, } \\
\text { Lateral rectus } \\
\text { involvement, } \\
\text { orbital, } \\
\text { Palatal bony } \\
\text { erosion }\end{array}$ & $\begin{array}{l}\text { Pan-sinusitis } \\
\text { with sinus } \\
\text { bony erosion }\end{array}$ & $\begin{array}{l}\text { Acute infarct of } \\
\text { left parietal, } \\
\text { centrum } \\
\text { semiovale, optic } \\
\text { nerve infiltration, } \\
\text { left inferior, } \\
\text { medial, lateral } \\
\text { rectus } \\
\text { involvement }\end{array}$ & $\begin{array}{l}\text { Right fronto- } \\
\text { parietal } \\
\text { infarct, B/L } \\
\text { pansinusitis } \\
\text { with bony } \\
\text { destruction }\end{array}$ & $\begin{array}{l}\text { Pansinusitis with } \\
\text { invasion of } \\
\text { medial, lateral, } \\
\text { inferior rectus } \\
\text { and optic nerve }\end{array}$ & $\begin{array}{l}\text { Pansinusitis } \\
\text { with Dural } \\
\text { enhancement of } \\
\text { B/L frontal } \\
\text { region }\end{array}$ & $\begin{array}{l}\text { Pan } \\
\text { ophthalmitis } \\
\text { with } \\
\text { pansinusitis, } \\
2.3 \times 2 \mathrm{~cm} \\
\text { frontal lobe } \\
\text { abscess }\end{array}$ & $\begin{array}{l}\text { Pans } \\
\text { with } \\
\text { erosi } \\
\text { pan } \\
\text { ophtl } \\
\text { acut } \\
\text { front } \\
\text { parie } \\
\text { occir }\end{array}$ \\
\hline
\end{tabular}

\begin{tabular}{|c|c|c|c|c|c|c|c|c|}
\hline \multirow{3}{*}{$\begin{array}{l}\text { Lab } \\
\text { abnormalities }\end{array}$} & \multirow{3}{*}{$\begin{array}{l}\text { Leucocytosis, } \\
\text { lymphopenia, } \\
\text { raised CRP, } \\
\text { elevated D- } \\
\text { Dimer }\end{array}$} & \multirow{3}{*}{$\begin{array}{l}\text { Lymphopenia } \\
\text { Raised CRP, } \\
\text { IL-6, elevated } \\
\text { D-dimer }\end{array}$} & \multirow{3}{*}{$\begin{array}{l}\text { Lymphopenia, } \\
\text { Raised CRP, IL-6, } \\
\text { elevated D-dimer }\end{array}$} & \multirow{3}{*}{$\begin{array}{l}\text { Leucocytosis, } \\
\text { Lymphopenia, } \\
\text { Raised CRP, } \\
\text { elevated D- } \\
\text { dimer }\end{array}$} & \multirow{3}{*}{$\begin{array}{l}\text { Lymphopenia } \\
\text { thrombo- } \\
\text { cytopenia } \\
\text { Raised CRP, IL-6, } \\
\text { elevated D-dimer }\end{array}$} & Lymphopenia & \multirow[t]{3}{*}{ Leucocytosis, } & \multirow{3}{*}{$\begin{array}{l}\text { Lymr } \\
\text { thror } \\
\text { cytor } \\
\text { Raise }\end{array}$} \\
\hline & & & & & & $\begin{array}{l}\text { IL-6, elevated D- } \\
\text { dimer }\end{array}$ & & \\
\hline & & & & & & & & \\
\hline Antifungal & $\begin{array}{l}\text { LAmB } \\
(5 \mathrm{mg} / \mathrm{kg})-\rightarrow \\
\text { stepdown Tab } \\
\text { Posaconazole } \\
300 \text { mg OD }\end{array}$ & $\begin{array}{l}\text { LAmB } \\
(5 \mathrm{mg} / \mathrm{kg})-> \\
\text { stepdown Tab } \\
\text { Posaconazole } \\
300 \text { mg OD }\end{array}$ & $\begin{array}{l}\text { LAmB }(3 \mathrm{mg} / \mathrm{kg}) \\
\text { + intraorbital } \\
\text { Ampho B }(1.5 \mathrm{mg} \\
\text { x 10days) }\end{array}$ & $\begin{array}{l}\mathrm{LAmB} \\
(5 \mathrm{mg} / \mathrm{kg})\end{array}$ & $\begin{array}{l}\text { LAmB }(3 \mathrm{mg} / \mathrm{kg}) \text { - } \\
\text { > stepdown Tab } \\
\text { Posaconazole } \\
300 \mathrm{mg} \mathrm{OD}\end{array}$ & $\begin{array}{l}\text { LAmB }(4 \mathrm{mg} / \mathrm{kg}) \\
\overrightarrow{\text { Tab stepdown }} \\
\text { Posaconazole } \\
300 \mathrm{mg} \text { OD }\end{array}$ & $\begin{array}{l}\text { LAmB } \\
(5 \mathrm{mg} / \mathrm{kg})-\overrightarrow{ } \\
\text { stepdown Tab } \\
\text { Posaconazole } \\
300 \mathrm{mg} \text { OD }\end{array}$ & $\begin{array}{l}\text { LAm } \\
(5 \mathrm{mg} \\
\text { stepc } \\
\text { Posa } \\
300\end{array}$ \\
\hline
\end{tabular}




\begin{tabular}{|c|c|c|c|c|c|c|c|c|}
\hline & Patient 1 & Patient2 & Patient 3 & Patient 4 & Patient 5 & patient 6 & patient 7 & Patic \\
\hline Surgery & $\begin{array}{l}\text { Infra- } \\
\text { structural } \\
\text { maxillectomy }\end{array}$ & $\begin{array}{l}\text { Infra- } \\
\text { structural } \\
\text { subtotal } \\
\text { maxillectomy }\end{array}$ & $\begin{array}{l}\text { Total } \\
\text { maxillectomy } \\
\text { with coronoid- } \\
\text { ectomy }\end{array}$ & - & $\begin{array}{l}\text { Total } \\
\text { maxillectomy } \\
\text { with orbital } \\
\text { exenteration }\end{array}$ & $\begin{array}{l}\text { FESS with } \\
\text { complete sinus } \\
\text { debridement } \\
\text { and posterior } \\
\text { ethmoid-otomy } \\
+ \\
\text { sphenoidotomy }\end{array}$ & $\begin{array}{l}\text { Orbital } \\
\text { exenteration } \\
\text { with sinus } \\
\text { debridement }\end{array}$ & $\begin{array}{l}\text { Hem } \\
\text { bulec } \\
\text { with } \\
\text { maxi } \\
\text { etmo } \\
\text { orbiti } \\
\text { exen }\end{array}$ \\
\hline $\begin{array}{l}\text { Time lag } \\
\text { between } \\
\text { diagnosis and } \\
\text { surgery }\end{array}$ & Day 40 & Day 16 & Day 17 & Not done & Day 25 & Day 7 & Day 19 & Day ، \\
\hline ICU admission & Yes & No & No & Yes & Yes & No & No & No \\
\hline Outcome & $\begin{array}{l}\text { Expired } 2 \\
\text { weeks after } \\
\text { discharge }\end{array}$ & $\begin{array}{l}\text { Discharged } \\
\text { and under } \\
\text { follow up }\end{array}$ & Expired & Expired & $\begin{array}{l}\text { Discharged and } \\
\text { under follow up }\end{array}$ & $\begin{array}{l}\text { Discharged and } \\
\text { under follow up }\end{array}$ & $\begin{array}{l}\text { Discharged } \\
\text { and under } \\
\text { follow up }\end{array}$ & $\begin{array}{l}\text { Discl } \\
\text { and I } \\
\text { follo }\end{array}$ \\
\hline Cause of death & $\begin{array}{l}\text { Unknow } \\
\text { cause (died at } \\
\text { home) }\end{array}$ & - & $\begin{array}{l}\text { Hospital } \\
\text { acquired } \\
\text { pneumonia }\end{array}$ & $\begin{array}{l}\text { DKA with } \\
\text { sepsis }\end{array}$ & - & - & - & - \\
\hline $\begin{array}{l}\text { Duration of } \\
\text { stay }\end{array}$ & 49 days & 66 days & 48 days & 3 days & 40 days & 31 days & 94 days & $49 \mathrm{~d}$ \\
\hline $\begin{array}{l}\text { LAmB } \\
\text { cumulative } \\
\text { dose }\end{array}$ & $7.8 \mathrm{gm}$ & $5.3 \mathrm{gm}$ & $6.5 \mathrm{gm}$ & $0.6 \mathrm{gm}$ & $6.4 \mathrm{gm}$ & $4.5 \mathrm{gm}$ & $13.7 \mathrm{gm}$ & $7.8 \mathrm{gr}$ \\
\hline $\begin{array}{l}\text { Amphotericin-B } \\
\text { toxicity }\end{array}$ & $\begin{array}{l}\text { Hypokalemia, } \\
\text { acute kidney } \\
\text { injury }\end{array}$ & $\begin{array}{l}\text { Hypo-kalemia, } \\
\text { hypo- } \\
\text { magnesemia, } \\
\text { acute kidney } \\
\text { injury, acute } \\
\text { infusion } \\
\text { reaction }\end{array}$ & $\begin{array}{l}\text { Hypo-kalemia, } \\
\text { Acute kidney } \\
\text { injury, Pan- } \\
\text { cytopenia }\end{array}$ & NA & $\begin{array}{l}\text { Hypo-kalemia, } \\
\text { hypomagnesemia }\end{array}$ & Pancytopenia & $\begin{array}{l}\text { Acute kidney } \\
\text { injury }\end{array}$ & $\begin{array}{l}\text { Acutı } \\
\text { injur }\end{array}$ \\
\hline
\end{tabular}

DM - Diabetes mellitus, DKA - diabetic keto-acidosis, CAD - coronary artery disease, CKD - Chronic kidney disease, CLD - chronic liver disease, CGD - chrc

Table 3

Risk factor for pre-existing mucormycosis $(n=16)$

\begin{tabular}{|ll|}
\hline Risk factors & Number of cases(percentage) \\
\hline Uncontrolled Diabetes mellitus & $10(75 \%)$ \\
\hline Chronic kidney disease & $2(12.5 \%)$ \\
\hline Post renal transplant (immunosuppressive agents) & $1(6.25 \%)$ \\
\hline Chronic liver disease & $1(6.25 \%)$ \\
\hline Pulmonary Tuberculosis (MDR-TB) & $1(6.25 \%)$ \\
\hline
\end{tabular}

All patients had confirmed COVID19 illness using SARS CoV-2 RT-PCR on nasopharyngeal or oropharyngeal swabs. Two patients were diagnosed with mucormycosis during convalescence from COVID19, whereas the rest had features suggestive of mucormycosis even before the diagnosis of COVID19. The median duration of symptoms was 15 days (range, 6-60 days). Laboratory abnormalities have been summarised in Table 2. The severity of COVID19 ranged from asymptomatic infection ( $n=5,31 \cdot 25 \%)$, mild $(n=7$, patients, $43 \cdot 75 \%)$, moderate (one patient, $6 \cdot 25 \%)$, and severe COVID19 requiring steroids and anticoagulation $(n=2,12.5 \%)$. Most of our patients had sino-nasal mucormycosis $(n=15)$ with or without orbital or intracranial involvement, with only one patient with pulmonary disease. Out of the fifteen patients with sino-nasal disease, five patients had localised disease, three had orbital involvement, and seven patients had evidence of intracranial spread. The diagnosis was established by demonstrating the fungal hyphae, in $\mathrm{KOH}$ mount and calcofluor fluorescent staining, with the characteristic feature of mucormycetes, while the fungus could be cultivated and identified as Rhizopus arrhizius in two cases and Rhizopus spp. in one case. While six cases had histopathological features of acute disease process i.e., coagulative necrosis or angioinvasion or perineural invasion, seven cases had granulomatous inflammation with giant cells, features suggestive of chronic mucormycosis. Radiological (CECT or CEMRI) findings have been summarised in Table 1. 
Table 2

Laboratory abnormalities of 16 patients with COVID-19 and mucormycosis

\begin{tabular}{|c|c|c|c|c|c|c|c|c|c|c|c|c|c|}
\hline & $\begin{array}{l}\text { Patient } \\
1\end{array}$ & $\begin{array}{l}\text { Patient } \\
2\end{array}$ & $\begin{array}{l}\text { Patient } \\
3\end{array}$ & $\begin{array}{l}\text { Patient } \\
4\end{array}$ & $\begin{array}{l}\text { Patient } \\
5\end{array}$ & $\begin{array}{l}\text { patient } \\
6\end{array}$ & patient & $\begin{array}{l}\text { Patient } \\
8\end{array}$ & $\begin{array}{l}\text { Patient } \\
9\end{array}$ & $\begin{array}{l}\text { Patient } \\
10\end{array}$ & $\begin{array}{l}\text { Patient } \\
11\end{array}$ & $\begin{array}{l}\text { Patient } \\
12\end{array}$ & $\begin{array}{l}\text { Patie } \\
13\end{array}$ \\
\hline Hemoglobin & 11.8 & 13.5 & 12 & 11.8 & 13.3 & 12.8 & 12.3 & 12.2 & 8.5 & 9.9 & 10.7 & 8.7 & 16 \\
\hline TLC & 14850 & 8900 & 6690 & 15340 & 7170 & 6330 & 13400 & 7200 & 7340 & 13080 & 14900 & 10200 & 1770 \\
\hline ALC & 787 & 676 & 1210 & 782 & 638 & 1196 & 1742 & 936 & 653 & 1124 & 2682 & 1632 & 1416 \\
\hline Platelets & 3.7Lac & 2.47Lac & 2.04Lac & 3.13lac & $0.91 \mathrm{Lac}$ & $0.52 \mathrm{Lac}$ & 3.21Lac & $0.95 \mathrm{Lac}$ & 1.83Lac & 2.43Lac & 2.93Lac & $\begin{array}{l}0 . \\
61 \mathrm{Lac}\end{array}$ & 2.47L \\
\hline Urea & 36.4 & 27 & 71 & 34 & 64 & 23.5 & 10 & 51 & 34.2 & 74.9 & 25 & 36 & 86 \\
\hline Creatine & 0.8 & 0.9 & 1.78 & 1.25 & 1.1 & 0.39 & 0.8 & 1.3 & 1.5 & 5.3 & 0.5 & 1 & 0.72 \\
\hline Potassium & 3.6 & 4.3 & 4.04 & 6.3 & 4 & 4 & 4.7 & 5.1 & 4 & 4.6 & 3.9 & 2.3 & 6.6 \\
\hline SGOT & 34 & 29 & 65 & 20 & 21 & 21 & 28 & 26 & 19 & 164 & 11 & 19 & 39 \\
\hline SGPT & 35 & 30 & 62 & 15 & 51 & 21 & 24 & 39 & 8 & 9 & 10 & 29 & 82 \\
\hline Ferritin & 1091 & 1954 & 838 & 1590 & 789 & 258 & - & 785 & 1175 & - & 370 & 508 & - \\
\hline CRP & 10.9 & 12.59 & 6.3 & 21.1 & 1.22 & 0.3 & - & 6.7 & 12.75 & 11.87 & 16.82 & 15.74 & - \\
\hline IL6 & - & 14.1 & 27 & - & 621.9 & 1.6 & - & - & 25.6 & - & 59.9 & 12.85 & - \\
\hline LDH & - & 309 & 234 & 451 & 560 & 241 & - & 232 & 143 & 282 & 175 & - & - \\
\hline D-dimer & 557 & 3428 & 456 & 538 & 1238 & 2016 & - & - & 1308 & 682 & - & 300 & - \\
\hline Fibrinogen & 523 & 624 & - & 702 & 193 & 255 & - & - & 417 & 289 & - & - & - \\
\hline
\end{tabular}

All patients were managed with Liposomal Amphotericin B (Fungisome) with or without surgical debridement. It was started at a dose of $3 \mathrm{mg} / \mathrm{kg}$ and escalated to $5 \mathrm{mg} / \mathrm{kg}$ if tolerated well. Adverse events necessitating alteration or discontinuation of therapy were nephrotoxicity $(\mathrm{n}=9,56 \cdot 25 \%)$, hypokalaemia $(n=8,50 \%)$, hypomagnesemia $(n=2,12 \cdot 5 \%)$ and bone marrow suppression $(n=2,12 \cdot 5 \%)$. Surgical intervention was done following two consecutive negative SARS CoV-2 RT-PCR results (at least 24 hours apart). Twelve patients (75\%) underwent surgery, two patients had fulminant disease and succumbed before medical stabilisation, and surgical intervention could be undertaken, one patient was planned for surgery, and one patient was lost to follow up. Surgical approaches included maxillectomy, orbital exenteration, and functional endoscopic sinus surgery, alone or in combination. The median duration of SARS CoV2 RT-PCR positivity was 16 days (IQR 10-24 days). The median duration between diagnosis of mucormycosis and surgical debridement was $22 \cdot 5$ days (IQR 17.75-29.5 days).

Out of the sixteen patients, five patients required admission to the intensive care unit (ICU), two due to severe COVID19, two patients due to diabetic ketoacidosis with severe metabolic acidosis, and one due to sudden drop in sensorium (due to progressive mucormycosis) (Table 1). The median duration of hospitalization was $40 \cdot 5$ days (IQR 27-49 days). There were six (37.5\%) mortalities in this cohort, all of them attributable to mucormycosis. Seven patients (43.75\%) patients have been discharged with step-down long term maintenance therapy with oral Posaconazole tablets (at a dosage of $300 \mathrm{mg}$ OD). Two patients $(6 \cdot 13 \%)$ were still admitted at the time of writing.

A literature search on pubmed for articles, published before February 20, 2021, using the terms "SARS CoV2" OR "COVID19" AND "Mucormycosis" AND "coinfection", yielded 11 published cases of COVID19 and mucormycosis. We analysed these twenty-seven cases (eleven case reports, sixteen cases from our study and divided them into categories based on if they developed mucormycosis before or after the COVID19 infection (Table 5). In patients with pre-COVID mucormycosis, sino-nasal disease (with or without orbital or cerebral involvement) was the most involved site, whereas in patients with post-COVID mucormycosis, the most common site was the lungs. Moreover, the need for mechanical ventilation was more common in post-COVID patients $(p<0.05)$.

Table 5 Characteristics of cases with Pre COVID vs Post COVID mucormycosis $(n=27)$ 


\begin{tabular}{|c|c|c|}
\hline & Pre COVID mucormycosis & Post COVID mucormycosis \\
\hline Number of cases* & $17(14+3)$ & $10(2+8)$ \\
\hline Age (years) & 45.3 (median 47, range - 24-75) & 54 (median 54, range - 34-86) \\
\hline Sex & $M: F-14: 3$ & $M: F-8: 2$ \\
\hline \multicolumn{3}{|l|}{ Severity of COVID-19 } \\
\hline Asymptomatic & 4 & 1 \\
\hline Mild & 7 & 1 \\
\hline Moderate & 3 & 0 \\
\hline Severe & 2 & 8 \\
\hline Unknown & 1 & 0 \\
\hline \multicolumn{3}{|l|}{ Site of mucormycosis } \\
\hline Sino-nasal (orbital or intracranial extension) & 16 & 3 \\
\hline Pulmonary & 1 & 6 \\
\hline Gastro-intestinal tract & 0 & 1 \\
\hline Others & 0 & 0 \\
\hline \multicolumn{3}{|l|}{ Risk factors } \\
\hline \multicolumn{3}{|l|}{ Pre-existing } \\
\hline Diabetes mellitus & 11 & 4 \\
\hline Chronic kidney disease & 1 & 2 \\
\hline Chronic liver disease & 1 & 0 \\
\hline Haematological malignancy & 1 & 2 \\
\hline Solid organ transplant & 0 & 1 \\
\hline MDR Pulm TB & 1 & 0 \\
\hline PID & 1 & 0 \\
\hline None & 1 & 3 \\
\hline COVID-19 hospitalisation related & $\mathrm{N}=17$ & $\mathrm{~N}=10$ \\
\hline Lymphopenia (<1500/ul) & $9(56.3 \%)$ & $8(80 \%)$ \\
\hline Steroids & $6(35.3 \%)$ & $7(70 \%)$ \\
\hline Anti-IL-6 agents & 0 & $3(30 \%)$ \\
\hline Mechanical ventilation & $1(5.9 \%)$ & $p$ value -0.000426 \\
\hline $\mathrm{H} / \mathrm{O}$ repeated nasopharyngeal or oropharyngeal swabs (>=2) & $16(94.1 \%)$ & $4(40 \%)$ \\
\hline \multicolumn{3}{|l|}{ Outcomes } \\
\hline Expired & 7 & $p$ value -0.0499 \\
\hline Discharged & 8 & 2 \\
\hline Admitted & 2 & 0 \\
\hline
\end{tabular}

* italicized number represent the number of cases published

\section{Discussion}

This study summarizes the experience of co-existing mucormycosis and COVID19 from our center and those reported in the literature so far. The incidence for the specific at-risk population for mucormycosis varies between 0.005 to 1.7 per million population (2). A recent multicentric study on the epidemiology of mucormycosis from India reported an increase in incidence rates from 24.7 to 89 cases per year (3); while another single-center based survey on people with diabetes reports an incidence of $0.15 \%$ (4). Only a few cases of COVID19-mucormycosis co-infection have been reported in literature to date (5-16). In our centre, the occurrence rate of co-existing COVID19-mucormycosis was 2.56 per 1000 COVID19 patients; the incidence rate of mucormycosis following COVID19 was $3 \cdot 2$ per 10,000 COVID19 patients. 
Comparing with the data prior to year 2020, current data is suggestive of increasing case of mucormycosis. There may be many causes for the increase in the incidence of COVID19. As part of the pandemic control strategy, active tracing of all contacts of COVID19 cases was being carried out along with screening of all cases, presenting to out-patient or emergency services, for SARS CoV-2 infection. As per national recommendations, all patients who tested positive were admitted regardless of symptomatology (17). This possibly explains the clustering of cases with mucormycosis in hospitals that were otherwise asymptomatic or previously undiagnosed. In our study, fourteen patients had symptoms suggestive of mucormycosis at admission, while the remaining two patients developed rhino-orbital mucormycosis nearly one month after the resolution of COVID19. The duration of diagnosis was variable, ranging from one week to three weeks.

Common mucormycosis (CM) occurs following inhalation of spores or inoculation of spores in wounds inflicted during trauma e.g., bomb blast injuries or road traffic accidents $(18,19)$. However, hospital acquired mucormycosis (HAM) secondary to surgical intervention, adhesive bandages, wooden tongue depressors, osteomy bags or contaminated linen etc. also has been reported $(20,21)$. Most common sites involved in HAM were skin followed by intrabdominal disease. The increased incidence of mucormycosis in the COVID19 may have many causes. The pandemic has caused widespread sociological and economic disturbances, severely restricting adequate access to healthcare. This has caused decompensation of previously well-controlled comorbidities in patients with chronic illnesses, like diabetes and chronic kidney disease. Furthermore, the incidence of hospital-acquired mucormycosis (HAM) has increased due to more exposure of at-risk individuals to Mucorales, in the setting of an altered host-immune response. Pre-existing conditions such as uncontrolled diabetes mellitus, solid organ transplants, haematological malignancy, neutropenia, or use of immunosuppressants predispose to the development of mucormycosis. It is noteworthy that exposure to molds is common in ICUs or wards close to construction sites, which was common in our case, where several newly built or previously unused buildings were repurposed as COVID19 facilities. Moreover, contaminated air, equipment, or linen may serve as sources of spores. Interventions such as swab tests (along with use of wooden tongue depressors), Ryle's tube insertion, insulin injections, etc. serve as a mode of inoculation into human tissues. The situation is further complicated using steroids or immunomodulators for severe COVID19, worsening glycaemic status, rampant use of antibiotics and voriconazole (empirically for CAPA), prolonged mechanical ventilation as well as prolonged hospitalisation.

In our cohort, sites of involvement were sino-nasal (with or without orbital or cerebral involvement) or lung parenchyma. Of the two patients (at our center) who developed mucormycosis following COVID19, one on immunosuppressants for renal transplant (and had received steroids for severe COVID19), and the other had end-stage renal disease. Both patients were diagnosed with rhino-orbital mucormycosis.

Amongst the cases reported in the literature, eight patients had risk factors for mucormycosis, i.e., diabetes mellitus $(n=6)$ and hematological malignancy $(n=$ 2) (Table 4). Moreover, eight cases received steroids for moderate to severe COVID19. Six had pulmonary mucormycosis, four had rhino-orbital-cerebral disease, and one patient had gastro-intestinal mucormycosis. Ten patientswere on mechanical ventilation before the diagnosis, while no such intervention was noted in the one with gastro-intestinal mucormycosis. Noteworthy here is the case reported by Pasero et. al. who developed pulmonary mucormycosis without any known risk factors; severe COVID19 and mechanical ventilation are potential risk factors in this case. Mechanical ventilation was a significant risk factor for developing post-COVID mucormycosis (Table 5). We did not find any patient developing mucormycosis, following COVID19, in the absence of obvious risk factors or severe COVID19 (possible use of steroids, mechanical ventilation). Lymphopenia is a common finding in COVID19, than neutropenia, whether COVID19 illness itself predisposes to mucormycosis is unclear yet $(22,23)$. According to one study, a protective role of Mucorales specific CD4 and CD8 T cells have been hypothesized during active mucormycosis (24). However, it will be interesting to know, whether COVID-19 related lymphocytopenia, results in impaired T cell Mucorales specific response and predispose to mucormycosis $(25)$. It is worth noting that thirteen patients $(81 \cdot 25 \%, n=16)$ had an absolute lymphocyte count less than 1500 cells/cumm (Table 2), however, the difference was not significant between pre-COVID and post-COVID mucormycosis cases (Table 5). 
Table 4

Summary of published case reports of co-infection COVID-19 and Mucormycosis ( $n=11)$

\begin{tabular}{|c|c|c|c|c|c|c|c|c|}
\hline Author & $\begin{array}{l}\text { Alekseyev et } \\
\text { al }\end{array}$ & Bellanger et al & Garg et al & Khan et al & $\begin{array}{l}\text { Mehta - } \\
\text { Pandey }\end{array}$ & $\begin{array}{l}\text { Monte Junior et } \\
\text { al }\end{array}$ & Pasero et al & Placik et al \\
\hline Country & USA & France & India & USA & India & Brazil & Italy & USA \\
\hline Age/Sex & $41 / \mathrm{M}$ & $55 / \mathrm{M}$ & $55 / \mathrm{M}$ & $44 / F$ & $60 / \mathrm{M}$ & $86 / \mathrm{M}$ & $66 / \mathrm{M}$ & $49 / \mathrm{M}$ \\
\hline Comorbidities & $\begin{array}{l}\text { Diabetes } \\
\text { mellitus }\end{array}$ & $\begin{array}{l}\text { Follicular } \\
\text { lymphoma, } \\
\text { Post HSCT }\end{array}$ & $\begin{array}{l}\text { Diabetes } \\
\text { mellitus, } \\
\text { Hypertension, } \\
\text { Ischemic } \\
\text { heart disease, } \\
\text { Chronic } \\
\text { Kidney } \\
\text { disease }\end{array}$ & $\begin{array}{l}\text { Diabetes } \\
\text { mellitus }\end{array}$ & $\begin{array}{l}\text { Diabetes } \\
\text { mellitus }\end{array}$ & Hypertension & Hypertension & None \\
\hline $\begin{array}{l}\text { Clinical } \\
\text { presentation }\end{array}$ & $\begin{array}{l}\text { Cough, } \\
\text { dysgeusia, } \\
\text { Nasal pain } \\
\text { with palatal } \\
\text { eschar }\end{array}$ & $\begin{array}{l}\text { Fever } \\
\text { Respiratory } \\
\text { distress }\end{array}$ & $\begin{array}{l}\text { Fever, cough, } \\
\text { dyspnea } \\
\text { New onset } \\
\text { expectoration }\end{array}$ & $\begin{array}{l}\text { Altered } \\
\text { sensorium. } \\
\text { Respiratory } \\
\text { distress }\end{array}$ & $\begin{array}{l}\text { Fever, } \\
\text { dyspnea, } \\
\text { malaise } \\
\text { Altered } \\
\text { mentation, } \\
\text { Right eye } \\
\text { proptosis, Left } \\
\text { eye loss of } \\
\text { vision }\end{array}$ & $\begin{array}{l}\text { Malena, } \\
\text { Abdominal } \\
\text { tenderness }\end{array}$ & $\begin{array}{l}\text { Dyspnea, } \\
\text { respiratory } \\
\text { distress }\end{array}$ & $\begin{array}{l}\text { Fever, coug } \\
\text { dyspnea } \\
\text { Pneumothc } \\
\text { with } \\
\text { bronchople } \\
\text { fistula }\end{array}$ \\
\hline $\begin{array}{l}\text { COVID-19 } \\
\text { severity }\end{array}$ & $\begin{array}{l}\text { Moderate (no } \\
\text { hypoxemia) }\end{array}$ & Mild & Severe & Severe & Severe & Severe & Severe & Severe \\
\hline $\begin{array}{l}\text { Timing of } \\
\text { Features s/o } \\
\text { Mucormycosis }\end{array}$ & At admission & $\begin{array}{l}19 \text { days after } \\
\text { admission (13 } \\
\text { days after } \\
\text { COVID-19 } \\
\text { diagnosis) }\end{array}$ & $\begin{array}{l}17 \text { days after } \\
\text { admission } \\
\text { due to COVID- } \\
19\end{array}$ & $\begin{array}{l}13 \text { days after } \\
\text { admission } \\
\text { due to COVID- } \\
19\end{array}$ & $\begin{array}{l}10 \text { days after } \\
\text { admission due } \\
\text { to COVID-19 }\end{array}$ & $\begin{array}{l}7 \text { days after } \\
\text { admission due } \\
\text { to COVID-19 }\end{array}$ & $\begin{array}{l}14 \text { days after } \\
\text { admission } \\
\text { due to COVID- } \\
19\end{array}$ & $\begin{array}{l}14 \text { days aft } \\
\text { admission } \\
\text { to COVID- } 1\end{array}$ \\
\hline $\begin{array}{l}\text { Site of } \\
\text { mucormycosis }\end{array}$ & $\begin{array}{l}\text { Rhino- } \\
\text { cerebral }\end{array}$ & Pulmonary & Pulmonary & Pulmonary & $\begin{array}{l}\text { Rhino-orbital } \\
\text { mucormycosis }\end{array}$ & Gastrointestinal & Pulmonary & Pulmonary \\
\hline $\begin{array}{l}\text { Risk factors } \\
\text { for } \\
\text { mucormycosis }\end{array}$ & $\begin{array}{l}\text { Uncontrolled } \\
\text { diabetes } \\
\text { mellitus } \\
\text { Diabetic } \\
\text { ketoacidosis }\end{array}$ & $\begin{array}{l}\text { Hematological } \\
\text { malignancy, } \\
\text { Mechanical } \\
\text { ventilation }\end{array}$ & $\begin{array}{l}\text { Uncontrolled } \\
\text { glycemic } \\
\text { status, } \\
\text { Steroids }\end{array}$ & $\begin{array}{l}\text { Uncontrolled } \\
\text { diabetes } \\
\text { mellitus, } \\
\text { Steroids }\end{array}$ & $\begin{array}{l}\text { Steroids - } \\
\text { Tocilizumab }\end{array}$ & Steroids & $\begin{array}{l}\text { None } \\
\text { No steroids }\end{array}$ & $\begin{array}{l}\text { Steroids, } \\
\text { Tocilizuma }\end{array}$ \\
\hline Imaging & $\begin{array}{l}\text { MRI: Sinusitis } \\
\text { with B/L } \\
\text { infratemporal } \\
\text { abscess and } \\
\text { cavernous } \\
\text { sinus } \\
\text { enhancement }\end{array}$ & $\begin{array}{l}\text { non-specific } \\
\text { bilateral } \\
\text { ground glass } \\
\text { opacities }\end{array}$ & $\begin{array}{l}\text { Thick-walled } \\
\text { cavity in right } \\
\text { upper lobe } \\
\text { with minimal } \\
\text { pleural } \\
\text { effusion }\end{array}$ & $\begin{array}{l}\text { GGO with } \\
\text { right multiple } \\
\text { cavitation }\end{array}$ & $\begin{array}{l}\text { Sinusitis with } \\
\text { bulky } \\
\text { extraocular } \\
\text { muscle and } \\
\text { proptosis }\end{array}$ & $\begin{array}{l}\text { Esophagogastro- } \\
\text { duodenoscopy: } \\
\text { Two gastric } \\
\text { ulcer with } \\
\text { haemorrhagic } \\
\text { base }\end{array}$ & $\begin{array}{l}\text { Left lung } \\
\text { cavitatory } \\
\text { lesion with } \\
\text { maxillary } \\
\text { sinusitis }\end{array}$ & $\begin{array}{l}\text { large } \\
\text { bronchople } \\
\text { fistula of th } \\
\text { right upper } \\
\text { lobe with } \\
\text { associated } \\
\text { necrotic } \\
\text { empyema }\end{array}$ \\
\hline $\begin{array}{l}\text { Basis of } \\
\text { diagnosis }\end{array}$ & $\begin{array}{l}\mathrm{KOH} \text { mount } \\
\text { on debrided } \\
\text { tissue }\end{array}$ & $\begin{array}{l}\text { Aspergillus } \\
\text { fumigatus } \\
\text { and Rhizopus } \\
\text { microsporus }\end{array}$ & $\begin{array}{l}\text { Culture - } \\
\text { Rhizopus } \\
\text { microsporus }\end{array}$ & $\begin{array}{l}\text { HPE of } \\
\text { endobronchial } \\
\text { biopsy } \\
\text { specimen }\end{array}$ & $\begin{array}{l}\text { Biopsy and } \\
\text { culture from } \\
\text { nasal mucosa }\end{array}$ & $\begin{array}{l}\text { HPE of } \\
\text { specimens from } \\
\text { ulcers }\end{array}$ & $\begin{array}{l}\text { Culture - } \\
\text { Rhizopus spp. }\end{array}$ & $\begin{array}{l}\text { Culture - } \\
\text { Rhizopus s }\end{array}$ \\
\hline Management & $\begin{array}{l}\text { Amphotericin- } \\
\text { B lipid } \\
\text { complex + } \\
\text { Sinus } \\
\text { debridement }\end{array}$ & $\begin{array}{l}\text { Liposomal } \\
\text { Amphotericin- } \\
\text { B (5mg/kg) }\end{array}$ & $\begin{array}{l}\text { Liposomal } \\
\text { Amphotericin- } \\
\text { B (3mg/kg) } \\
\text { Awaiting } \\
\text { surgery }\end{array}$ & $\begin{array}{l}\text { Liposomal } \\
\text { amphotericin- } \\
\text { B (5mg/kg) }\end{array}$ & $\begin{array}{l}\text { Amphotericin- } \\
\text { B (0.5mg/kg) }\end{array}$ & $\begin{array}{l}\text { No antifungal or } \\
\text { surgical therapy }\end{array}$ & $\begin{array}{l}\text { Liposomal } \\
\text { Amphotericin- } \\
\mathrm{B}(5 \mathrm{mg} / \mathrm{kg}) \\
\text { and } \\
\text { Isavuconazole }\end{array}$ & $\begin{array}{l}\text { Amphoteric } \\
\text { B + Right } \\
\text { middle } \\
\text { thoracoton } \\
\text { resection o } \\
\text { diseased al } \\
+ \text { fistula rer } \\
\text { and } \\
\text { pleurodesis }\end{array}$ \\
\hline Outcome & Discharged & Died & Discharged & Died & Died & Died & Died & Died \\
\hline
\end{tabular}

The starkest aspect of co-existing mucormycosis and COVID19 was the impact on the management of mucormycosis. Mucormycosis is a fulminant disease and a surgical emergency. Its management requires a combination of extensive surgical debridement to remove infected tissue as well as medical therapy (2, 18 ,26). Despite both surgery and antifungal, it is associated with high mortality and morbidity. It has been observed that surgery performed during active COVID19 disease is associated with poor outcomes $(27,28)$. Furthermore, there is a risk to operating room personnel during surgery due to aerosol-generating 
procedures like intubation and endotracheal tube suction. A general consensus during COVID-19 pandemic is to postpone all elective surgeries, while all emergency surgery requires utmost consideration to indication, urgency of surgery, surgical approach, risk of aerosol spread, and availability of staff and resources $(29,30)$. All our patients were started on medical management with antifungal agents at diagnosis. We found that in most cases, surgery was delayed till medical stabilisation and RT-PCR negativity. The median duration between diagnosis of mucormycosis and surgical debridement was 22.5 days (IQR 17.75-29.5 days). Surgery was performed in twelve cases. Two patients deteriorated rapidly and could not be taken up for surgery; one was lost to follow up, and one patient was awaiting surgery following medical stabilisation. Our cohort had six mortalities, including four patients who had undergone surgical debridement. Of these, five were of sino-nasal mucormycosis, while one patient had pulmonary involvement. In reported literature, two out of eleven cases, had rapidly worsening severe COVID19 and succumbed to severe illness before surgery or medical therapy. Other patients were managed medically with one or more antifungals, i.e., Liposomal Amphotericin B or isavuconazole. Surgery was undertaken in only three patients, while the rest were deemed medically unfit for surgical intervention. Ten out of eleven patients died despite medical therapy and surgery.

This study is the largest account of COVID19 and mucormycosis co-infection available in the literature. Having been done at a tertiary care centre equipped to diagnose and treat both COVID19 and mucormycosis with alacrity, our study is uniquely equipped to identify disease-related, patient-related, and treatmentrelated factors leading to poor outcomes. Limitations of our study include a descriptive design. The lack of a non-COVID19 infected control group limits our ability to distinguish COVID19 specific considerations in the broader background of the socio-economic upheaval caused by the pandemic. Further research is required to establish if COVID19 itself predisposes to mucormycosis.

\section{Conclusion}

There has been an apparent increase in the incidence of mucormycosis in patients of COVID19. The causes for this are multi-factorial, including decreased access to healthcare leading to decompensation of underlying comorbidities, increased exposure to healthcare facilities leading to more Hospital Acquired Mucormycosis (HAM), and increased use of immunosuppressants in the setting of COVID19. Patients with mucormycosis with COVID19 co-infection have poorer outcomes which may be related to immunosuppression administered for the COVID19 infection and delays in access to adequate surgical management.

\section{Declarations}

Acknowledgements

There were no conflicts of interest.

Written informed was obtained from all patients or their relatives.

Funding - nil

\section{References}

1. Koehler P, Bassetti M, Chakrabarti A, Chen SCA, Colombo AL, Hoenigl M, et al. Defining and managing COVID-19-associated pulmonary aspergillosis: the 2020 ECMM/ISHAM consensus criteria for research and clinical guidance. The Lancet Infectious Diseases. 2020 Dec 14;0(0). Available from: https://www.thelancet.com/journals/laninf/article/PIIS1473-3099(20)30847-1/abstract

2. Jeong W, Keighley C, Wolfe R, Lee WL, Slavin MA, Kong DCM, et al. The epidemiology and clinical manifestations of mucormycosis: a systematic review and meta-analysis of case reports. Clinical Microbiology and Infection. 2019 Jan 1;25(1):26-34. Available from:

http://www.sciencedirect.com/science/article/pii/S1198743X18305299

3. Prakash H, Ghosh AK, Rudramurthy SM, Singh P, Xess I, Savio J, et al. A prospective multicenter study on mucormycosis in India: Epidemiology, diagnosis, and treatment. Medical Mycology. 2019 Jun 1;57(4):395-402. Available from: https://academic.oup.com/mmy/article/57/4/395/5063412

4. Bhansali A, Bhadada S, Sharma A, Suresh V, Gupta A, Singh P, et al. Presentation and outcome of rhino-orbital-cerebral mucormycosis in patients with diabetes. Postgrad Med J. 2004 Nov;80(949):670-4. Available from: https://www.ncbi.nlm.nih.gov/pmc/articles/PMC1743145/

5. Mehta S, Pandey A. Rhino-Orbital Mucormycosis Associated With COVID-19. Cureus. 2020 Sep 30;12(9):e10726.

6. Monte Junior ES do, Santos MELD, Ribeiro IB, Luz G de O, Baba ER, Hirsch BS, et al. Rare and Fatal Gastrointestinal Mucormycosis (Zygomycosis) in a COVID-19 Patient: A Case Report. Clin Endosc. 2020 Nov;53(6):746-9.

7. Pasero D, Sanna S, Liperi C, Piredda D, Branca GP, Casadio L, et al. A challenging complication following SARS-CoV-2 infection: a case of pulmonary mucormycosis. Infection. 2020 Dec 17;

8. Placik DA, Taylor WL, Wnuk NM. Bronchopleural fistula development in the setting of novel therapies for acute respiratory distress syndrome in SARSCoV-2 pneumonia. Radiol Case Rep. 2020 Nov;15(11):2378-81.

9. Werthman-Ehrenreich A. Mucormycosis with orbital compartment syndrome in a patient with COVID-19. Am J Emerg Med. 2020 Sep 16;

10. Khan N, Gutierrez CG, Martinez DV, Proud KC. A case report of COVID-19 associated pulmonary mucormycosis. Archive of Clinical Cases. 2021 Jan 8;7(3):2020-7(3):46-51. Available from: https://www.clinicalcases.eu/index.php/acc/article/view/562

11. Zurl C, Hoenigl M, Schulz E, Hatzl S, Gorkiewicz G, Krause R, et al. Autopsy Proven Pulmonary Mucormycosis Due to Rhizopus microsporus in a Critically III COVID-19 Patient with Underlying Hematological Malignancy. Journal of Fungi. 2021 Feb;7(2):88. Available from: https://www.mdpi.com/2309$608 \mathrm{X} / 7 / 2 / 88$

Page $9 / 10$ 
12. Alekseyev K, Didenko L, Chaudhry B. Rhinocerebral Mucormycosis and COVID-19 Pneumonia. Journal of Medical Cases. 2021 Jan 19;12(3):85-89-89. Available from: https://www.journalmc.org/index.php/JMC/article/view/3637

13. Garg D, Muthu V, Sehgal IS, Ramachandran R, Kaur H, Bhalla A, et al. Coronavirus Disease (Covid-19) Associated Mucormycosis (CAM): Case Report and Systematic Review of Literature. Mycopathologia. 2021 Feb 5;

14. Waizel-Haiat S, Guerrero-Paz JA, Sanchez-Hurtado L, Calleja-Alarcon S, Romero-Gutierrez L. A Case of Fatal Rhino-Orbital Mucormycosis Associated With New Onset Diabetic Ketoacidosis and COVID-19. Cureus;13(2). Available from: https://www.ncbi.nlm.nih.gov/pmc/articles/PMC7870113/

15. Bellanger A-P, Navellou J-C, Lepiller Q, Brion A, Brunel A-S, Millon L, et al. Mixed mold infection with Aspergillus fumigatus and Rhizopus microsporus in a Severe Acute Respiratory syndrome Coronavirus 2 (SARS-CoV-2) patient. Infect Dis Now. 2021 Jan 27; Available from: https://www.ncbi.nlm.nih.gov/pmc/articles/PMC7839422/

16. Hanley B, Naresh KN, Roufosse C, Nicholson AG, Weir J, Cooke GS, et al. Histopathological findings and viral tropism in UK patients with severe fatal COVID-19: a post-mortem study. Lancet Microbe. 2020 Oct;1(6):e245-53.

17. UpdatedClinicalManagementProtocolforCOVID19dated03072020.pdf. Available from: https://www.mohfw.gov.in/pdf/UpdatedClinicalManagementProtocolforCOVID19dated03072020.pdf

18. Petrikkos G, Skiada A, Lortholary O, Roilides E, Walsh TJ, Kontoyiannis DP. Epidemiology and clinical manifestations of mucormycosis. Clin Infect Dis. 2012 Feb;54 Suppl 1:S23-34.

19. Ibrahim AS, Spellberg B, Walsh TJ, Kontoyiannis DP. Pathogenesis of Mucormycosis. Clinical Infectious Diseases. 2012 Feb 1;54(suppl_1):S16-22. Available from: https://doi.org/10.1093/cid/cir865

20. Rammaert B, Lanternier F, Zahar J-R, Dannaoui E, Bougnoux M-E, Lecuit M, et al. Healthcare-Associated Mucormycosis. Clinical Infectious Diseases. 2012 Feb 1;54(suppl_1):S44-54. Available from: https://doi.org/10.1093/cid/cir867

21. Antoniadou A. Outbreaks of zygomycosis in hospitals. Clinical Microbiology and Infection. 2009 Jan 1;15:55-9. Available from: http://www.sciencedirect.com/science/article/pii/S1198743X14607308

22. Gupta A, Madhavan MV, Sehgal K, Nair N, Mahajan S, Sehrawat TS, et al. Extrapulmonary manifestations of COVID-19. Nat Med. 2020 Jul;26(7):1017-32. Available from: http://www.nature.com/articles/s41591-020-0968-3

23. Terpos E, Ntanasis-Stathopoulos I, Elalamy I, Kastritis E, Sergentanis TN, Politou M, et al. Hematological findings and complications of CoVID-19. Am J Hematol. 2020 May 23; Available from: https://www.ncbi.nlm.nih.gov/pmc/articles/PMC7262337/

24. Potenza L, Vallerini D, Barozzi P, Riva G, Forghieri F, Zanetti E, et al. Mucorales-specific T cells emerge in the course of invasive mucormycosis and may be used as a surrogate diagnostic marker in high-risk patients. Blood. 2011 Nov 17;118(20):5416-9. Available from: https://doi.org/10.1182/blood-2011-07366526

25. Liu J, Li S, Liu J, Liang B, Wang X, Wang H, et al. Longitudinal characteristics of lymphocyte responses and cytokine profiles in the peripheral blood of SARS-CoV-2 infected patients. EBioMedicine. 2020 May 1;55. Available from: https://www.thelancet.com/journals/ebiom/article/PIIS23523964(20)30138-9/abstract

26. Cornely OA, Alastruey-Izquierdo A, Arenz D, Chen SCA, Dannaoui E, Hochhegger B, et al. Global guideline for the diagnosis and management of mucormycosis: an initiative of the European Confederation of Medical Mycology in cooperation with the Mycoses Study Group Education and Research Consortium. The Lancet Infectious Diseases. 2019 Dec 1;19(12):e405-21. Available from: http://www.sciencedirect.com/science/article/pii/S1473309919303123

27. Nepogodiev D, Bhangu A, Glasbey JC, Li E, Omar OM, Simoes JF, et al. Mortality and pulmonary complications in patients undergoing surgery with perioperative SARS-CoV-2 infection: an international cohort study. The Lancet. 2020 Jul;396(10243):27-38. Available from: https://linkinghub.elsevier.com/retrieve/pii/S014067362031182X

28. Couloigner V, Schmerber S, Nicollas R, Coste A, Barry B, Makeieff M, et al. COVID-19 and ENT Surgery. Eur Ann Otorhinolaryngol Head Neck Dis. 2020 May;137(3):161-6. Available from: https://www.ncbi.nlm.nih.gov/pmc/articles/PMC7177055/

29. Atru B, Sutrave M, George R, James R, Ross A, C.B P. Otolaryngology Surgical Activity in Tertiary Care Center During the Covid-19 Lockdown. Indian J Otolaryngol Head Neck Surg. 2020 Oct 1; Available from: https://doi.org/10.1007/s12070-020-02155-7

30. Givi B, Schiff BA, Chinn SB, Clayburgh D, lyer NG, Jalisi S, et al. Safety Recommendations for Evaluation and Surgery of the Head and Neck During the COVID-19 Pandemic. JAMA Otolaryngol Head Neck Surg. 2020 Jun 1;146(6):579. Available from: https://jamanetwork.com/journals/jamaotolaryngology/fullarticle/2764032 